\title{
What have the genomics ever done for the psychoses?
}

\author{
M. Gill*, G. Donohoe and A. Corvin \\ Neuropsychiatric Genetics Research Group, Department of Psychiatry, School of Medicine, Trinity College Dublin, Ireland
}

Background. Despite the substantial heritability of the psychoses and their genuine public health burden, the applicability of the genomic approach in psychiatry has been strongly questioned or prematurely dismissed.

Method. A selective review of the recent literature on molecular genetic and genomic approaches to the psychoses including the early output from genome-wide association studies and the genomic analysis of DNA structural variation.

Results. Susceptibility variants at strong candidate genes have been identified including neuregulin, dysbindin, DISC1 and neurexin 1. Rare but highly penetrant copy number variants and new mutations affecting genes involved in neurodevelopment, cell signalling and synaptic function have been described showing some overlapping genetic architecture with other developmental disorders including autism. The de-novo mutations described offer an explanation for the familial sporadic divide and the persistence of schizophrenia in the population. The functional effects of risk variants at the level of cognition and connectivity has been described and recently, ZNF804A has been identified, and the MHC re-identified as risk loci, and it has been shown that at least a third of the variation in liability is due to multiple common risk variants of small effect with a substantial shared genetic liability between schizophrenia and bipolar affective disorder.

Conclusions. The genomics have done much for the psychoses to date and more is anticipated.

Received 8 June 2009; Revised 27 July 2009; Accepted 1 August 2009; First published online 12 October 2009

Key words: Copy number variation, DNA variants, genetics, psychosis, schizophrenia.

\section{Introduction}

From classical family, twin and adoption studies, the major psychoses are strongly familial and have a substantial genetic component. As with other complex genetic disorders, the underlying genetic models involved are far from certain, but are likely to involve interaction between multiple genetic and possibly environmental risk factors. Given that these disorders have a significant public health impact, are only partially amenable to current treatments, and are not readily preventable by environmental change, identifying genes and underlying pathophysiology is of more than academic interest (Merikangas \& Risch, 2003). The emergence of molecular genetics offered the hope that such genetic variants could be identified, potentially illuminating the pathophysiology involved. However, because of the nature of the problem-identifying multiple small effects contributing risk, rather than large genetic effects causing Mendelian

\footnotetext{
* Address for correspondence: Professor M. Gill, Department of Psychiatry, Trinity Center for Health Sciences, St. James' Hospital, Dublin 8, Ireland.

(Email: mgill@tcd.ie)
}

disorders - and the investigative tools available, we remain (largely) in the dark as to the nature of the genetic mechanisms involved.

With the early developments in molecular genetic methodology, family-based studies identified regions of the genome genetically linked to a number of Mendelian disorders. Due to limitations of the molecular resources available at the time, for conditions such as Huntington's disease, it took many years following the initial identification of genetic linkage to the disorder before causative mutations were identified. However, technologies improved, the Human Genome Project began and successes with Mendelian disorders began to pile up. Similar work began for neuropsychiatric disorders despite well recognized problems including the delineation of the diagnostic boundaries of the particular disorder, and the lack of obvious models of transmission. Penrose (1971) began his editorial in this journal with 'Genetics and psychiatry make strange bedfellows'. This can still be said today, with molecular genetics having little or no impact as yet on clinical psychiatry.

There has been scepticism from the early days about the use of molecular genetic methods for any 
common complex disorder, but particularly relating to psychiatric or behavioural disorders (Rose, 1998). This scepticism was given apparent substance by the lack of reliable findings emerging from what was becoming an extensive literature of linkage and association studies (van den Oord, 2002). The field was not encouraged by initial results with some high-profile reports of genetic linkage for both bipolar affective disorder (Egeland et al. 1987) and schizophrenia (Sherrington et al. 1988), emerging as false-positive findings (Kelsoe et al. 1989). The early association studies also brought criticism for the small samples used and for the statistical handling of multiple testing. It was observed that success would depend on the underlying genetic model and that if, for example, there was very significant phenotypic and genetic heterogeneity - the multiple rare variant model - then linkage might be successful in some large multiply affected families, but with the absence of common risk variants, that association studies would fail. That psychiatric genetics might become the graveyard of molecular genetics (Owen, 1992) was a serious consideration.

Genomics, in particular the recently demonstrated ability of genome-wide association studies (GWAS) to identify common risk variants for other disorders of public-health significance, is transforming medicine. The list of genetic variants reliably associated with common human disease has expanded from singledigits to hundreds in less than 2 years (http://www. genome.gov/GWAstudies/). More than simply confirming suspected genes these data have lead to novel genetic findings and new avenues for investigating the biology of, inter alia, type 2 diabetes, inflammatory bowel disease and breast cancer (Zeggini et al. 2008). Clinically this is identifying relationships between disorders (Dubois \& van Heel, 2008) and suggesting potential applications such as improving screening programmes for breast cancer (Pharoah et al. 2008) or predicting therapeutic response to warfarin therapy (Schwartz et al. 2008). Unsurprisingly, testing a million genetic markers for small genetic effects in one experiment poses a multiple-testing problem: a study of 1500 cases and 1500 controls has only $13 \%$ power to detect an allele conferring modest risk [odds ratio $(\mathrm{OR})=1.3$ ] for a variant with $20 \%$ frequency in the population. Success in the three medical disorders described has required pooled GWAS data from 5000 to 20000 subjects. In each case only a small proportion, typically less than $5 \%$, of genetic variance has been explained: in illuminating genetic architecture of complex disease this is candles in the darkness rather than the flicking of a switch.

Despite the substantial heritability of the psychoses and other neuropsychiatric disorders and their genu- ine public health burden, the applicability of this approach in psychiatry has been strongly questioned or prematurely dismissed (Rose, 1998; Crow, 2008). Data from the large Psychiatric GWAS Consortium (of five disorders including the major psychoses and autism) should be available during 2009, but contrary to the 'candle-snuffing' view, promising findings have already been reported in bipolar affective disorder, schizophrenia and autism (Ferreira et al. 2008; O'Donovan et al. 2008; Wang et al. 2009). GWAS are only one type of experiment, addressing the contribution of common genetic variants of modest effect to susceptibility: the experience of other human diseases tells us that these studies are likely to explain a small, albeit potentially biologically important, component of genetic variance, and additional approaches such as high throughput sequencing are likely to be required to identify rare variants. The 1000 Genomes Project (http://www.1000genomes.org/page.php), is already underway to support this approach.

With the completion of the human genome project and the HapMap project; with exponentially increasing knowledge of individual gene structure, regulation and function; with new Chip-based technologies able to examine most of the common genetic variations and some of the structure of the genome in a single experiment; with gene expression Chip arrays and high throughput sequencing, has there been any important advances in our knowledge of the aetiology of neuropsychiatric disorders? To paraphrase the line from the Monty Python film (for readers not familiar with this film, a clip of the relevant scene is available at http:/ / www.youtube.com/watch?v=ExWfh6sGyso\& feature $=$ related $)$ :

What have the genomics ever done for the psychoses?

Asking this question some years ago, the reply after a pause to stretch the definition of the psychoses would have been:

The identification of APP and Presenilin mutations and ApoEs4 as a general risk factor in Alzheimer's disease?

Autosomal dominant Alzheimer's disease accounts for only $5-10 \%$ of all clinically presented cases and includes mutations around the processing sites of the APP molecule resulting in increased production of the $\beta$-amyloid peptide; multiple different mutations in the PSEN1 gene increasing production of $\mathrm{A} \beta 42$, and mutations within PSEN2 resulting in increased $\beta$-amyloid production. ApoE $\varepsilon 4$ is the only molecule that has been associated with all of the biochemical disturbances of the disease including $\beta$-amyloid production, fibrillary tangle formation, oxidative stress, 
lipid metabolism, synaptic plasticity and cholinergic dysfunction (Cedazo-Minguez, 2007). The insights into the pathophysiology of Alzheimer's disease as a result of genetic findings have suggested novel therapeutic strategies, some of which are in the early stages of clinical trials.

So, apart from identifying $\beta$-amyloid production, fibrillary tangle formation, oxidative stress, lipid metabolism, synaptic plasticity and cholinergic dysfunction as key features of Alzheimer's disease, what have the genomics done for the psychoses?

The identification by linkage and association methods of neuregulin and dysbindin genes as risk genes for schizophrenia?

Neuregulin 1 (NRG1) is a large complex gene spanning $1.1 \mathrm{Mb}$, and belongs to a family of growth and differentiation factors that interact with the ErbB tyrosine kinase transmembrane receptors. Following suggestive evidence of linkage to chromosome $8 \mathrm{p}$ in a study of 33 Icelandic families, the deCode group identified several risk haplotypes within this region in a large case-control sample (Stefansson et al. 2002). The core risk haplotype located at the $5^{\prime}$ end of NRG1 was later replicated in a Scottish sample and, in truncated form, in an Irish sample (Corvin et al. 2004). The pattern of both positive and negative results since then, analysed in two follow-up meta-analyses, suggests support for involvement of the locus, but also evidence of genetic heterogeneity. Resolving the presence, or indeed, absence of complex genetic mechanisms at putative susceptibility loci is likely to be answered only by high-throughput DNA sequencing experiments.

NRG1 is also implicated in biological processes thought to be involved in schizophrenia - including glutamatergic $N$-methyl-D-aspartate (NMDA) receptor function and myelination. This positions NRG1 as both a functional and positional candidate gene for the disorder, making the efforts to tease apart the complexity of its contribution valuable as a model for investigating other susceptibility genes. Animal and human post-mortem studies suggest that NRG1 stimulation suppresses NMDA receptor activation in the prefrontal cortex and that this suppression may be more pronounced in schizophrenia (Hahn et al. 2006). Neurodevelopmental roles include attracting (GABAergic) interneurons towards the cortex through its ErbB4 signalling partner, facilitating thalamocortical connectivity (López-Bendito et al. 2006), and synapse development (Harrison \& Law, 2006). Identified risk variants at NRG1 are associated with reduced whitematter volume and/or white-matter integrity in patients and controls (McIntosh et al. 2008). Consistent with this role in grey- and white-matter structure and function, and with its role in NMDA receptor activity, risk variants at NRG1 have also been associated with variance in multiple behavioural and neuroimaging indices of cognition, although further replication of this work is required (Stefanis et al. 2007).

Dysbindin 1. Evidence for the involvement of the dystrobrevin-binding protein 1 (DTNBP1; dysbindin) gene came from a dense fine-mapping study of the chromosome $6 \mathrm{p}$ susceptibility locus in affected Irish families. The DTNBP1 association now has been reported in more than 10 independent samples (Williams et al. 2005) and studies have again differed in the alleles/haplotypes reported. As with NRG1, the lack of a clear risk variant precludes definitive evidence of statistical association. However, there is additional functional evidence implicating the gene in schizophrenia susceptibility, even if its cellular functions are poorly understood. DTNBP1 binds synaptic and microtubule-interacting proteins (Talbot et al. 2004; Camargo et al. 2007), some of which interact with DISC1, suggesting a link between these two pathways and the possible involvement of DTNBP1 in cell migration or other aspects of neural development. Expression studies have suggested a role for dysbindin in decreased exocytosis of glutamate-containing synaptic vesicles (Bray et al. 2005; Weickert et al. 2004). In the dysbindin mutant mouse 'Sandy', use of SiRNA to decrease availability of both dysbindin and a related gene Muted leads to decreased dopamine levels, and impaired internalization of $\mathrm{D}_{2}$ receptors from the cell surface and increased intracellular trafficking (lizuka et al. 2007). This suggests a novel regulatory pathway associated with dysbindin; whether this is a main effect, or some compensatory effect, of dysbindin remains to be confirmed.

Consistent with evidence that DTNBP1 may be associated with a clinical presentation involving more enduring and disabling features of psychosis (Fanous et al. 2005; Corvin et al. 2008), a series of studies have associated dysbindin risk variants with poorer cognitive function. This association has been with poorer performance in both higher cognitive domains in controls (Burdick et al. 2005; Fallgatter et al. 2006) and with both general and domain-specific deficits in schizophrenia (Burdick et al. 2006; Fallgatter et al. 2006; Donohoe et al. 2007). The dysbindin risk variant is also associated with significant deficits in early visual processing, indexed by the P1 response (Donohoe et al. 2008). Both this 'general' impact on cognition and the association with a more 'trait-like' schizophrenia presentation reflected in an association with poorer pre-morbid functioning in early onset 
schizophrenia (Burdick et al. 2007), has contributed to the idea of dysbindin as a 'prototypical' schizophrenia gene.

So apart from Alzheimer's disease; identifying neuregulin and dysbindin, genes involved in basic biological functions such as nerve cell growth and differentiation, myelination, cell structure and motility, NMDA receptor function and dopaminergic system modulation, what have the genomics done for the psychoses?

\section{Chromosomal abnormalities and risk of psychosis - Velocardiofacial syndrome (VCFS), Disrupted in Schizophrenia (DISC1) and DNA copy number variation $(\mathrm{CNV})$ ?}

Many common syndromes have been shown to be related to chromosomal abnormalities. Early examples included trisomy 21 in Down's syndrome, deletion of chromosome $5 \mathrm{p}$ in cri-du-chat, a fragile $\mathrm{X}$ chromosome site in a syndrome with a variable but characteristic set of physical abnormalities and cognitive impairment, and a reciprocal translocation involving chromosomes 9 and 22 in chronic myeloid leukaemia - the 'Philadelphia chromosome'. An expanding group of genomic disorders have been described, each caused by a structural or CNV in the genome

Chromosome examination in cases with psychosis has not been a common clinical investigation but there are multiple case and short series reports of chromosomal abnormalities in such cases, particularly when the psychosis is associated with cognitive impairment (Demirhan \& Tastemir, 2003; MacIntyre et al. 2003). Abnormalities in single cases or in small families have been reported for almost all chromosomes but rarely have there been multiple independent cases with the same abnormality, or multiple cases in the same family with evidence of linkage between the psychosis phenotype and the abnormality. There are, however, important examples for both of these scenarios; the $22 \mathrm{q}$ microdeletion, reported in multiple cases, and the $1: 11$ translocation with significant evidence of linkage to psychoses and other psychiatric diagnoses in a large Scottish family.

\section{VCFS}

A microdeletion at $22 \mathrm{q} 11.2$, is responsible for VCFS, also known as DiGeorge syndrome, a syndrome that is associated with a wide range of variable clinical features including a characteristic physiognomy, cardiac defects, palate abnormalities, learning disability and a rate of psychosis some 20-30 times greater than in the general population (Gothelf et al. 2008). The microdeletion is typically of $\sim 3 \mathrm{Mb}$ but is smaller in some cases. Recent use of microarray technology allows for much greater resolution showing small but significant differences between deletions apparently the same using conventional cytogenetic methods (Urban et al. 2006). VCFS has provided a model for investigation of the biological basis of psychosis, with most individuals having 40 genes deleted, including among them COMT and PRODH, genes also reported to be associated with non-VCFS psychosis (Karayiorgou \& Gogos, 2004; Arinami, 2006). The increased risk for schizophrenia is thought to be due to haploinsufficiency of one or more of the genes involved. Mouse models with an engineered deletion similar to the human deletion show deficits in sensorimotor gating and cognitive impairment (Paylor \& Lindsay, 2006). Stark et al. (2008) have engineered a mouse model by deleting the mouse sequence relating to the smaller $1.5 \mathrm{Mb}$ deletion region in humans, including the genes COMT, PRODH and DGCR8. These mice show dysregulation of genes outside the deletion region, including those involved in synaptic transmission. Other mutation studies in mice have implicated TBX1, a member of the T-box family of transcription factors. Altered TBX1 dosage appears to account for most of the VCFS equivalent phenotype in mice (Liao et al. 2004; Aggarwal \& Morrow, 2008). Supporting this finding is the identification of inactivating TBX1 mutations in rare non-deleted VCFS patients (Paylor et al. 2006).

\section{DISC1}

Interest in the DISC1 locus spans almost 40 years since a balanced translocation at $1: 11$ (q42; q14.3) was initially reported in an individual with adolescent conduct disorder (Jacobs et al. 1970), and later identified in several additional family members who also presented with major psychiatric disorders (St Clair et al. 1990). Detailed clinical investigation of the family and a linkage analysis generated odds score of 3.6 when schizophrenia was taken as the phenotype, increasing to 7.1 when relatives who had bipolar disorder and recurrent major depression also were included (Blackwood et al. 2001). The breakpoint on chromosome 1 disrupted two overlapping and opposite sense genes, DISC1 and DISC2. DISC1 gene has at least 13 exons and spans more than $300 \mathrm{~kb}$, with exon 8 comprising one third of this area. Protein expression associated with DISC1 is disrupted within intron 8, removing exons 9-13 to chromosome 11 . Association studies of DNA variants around these genes in Finnish, North American, Scottish, Japanese, and Han Chinese populations suggest that DNA variation, in addition to disruption caused by translocation, confers susceptibility to major mental illness 
(Hennah et al. 2003; Cannon et al. 2005; Kilpinen et al. 2008; Chubb et al. 2008). Some of these findings require further replication, and DNA variation at the gene may yet prove to be a very rare cause of disorder, nonetheless, the emerging neurobiology associated with the translocation mutation is increasingly compelling as outlined below.

Implication of the DISC1 protein in multiple cell functions including cAMP signalling, centrosomal and microtubule-based functions, kenesin-mediated intracellular transport and neurite extension have led to its description as a 'hub protein' for both the developing and adult brain (Schurov et al. 2004; Sawamura \& Sawa, 2006; Chubb et al. 2008). Intriguingly, these functions may alternate depending on the stage of development-with important implications for brain plasticity-particularly within the hippocampus. Austin et al. (2004) reported that embryonic brain development in DISC1 knockdown mice was associated with inhibited neuronal migration and dendritic arborization. By contrast, Duan et al. (2007) found that injecting retroviral vectors expressing DISC1 shRNA into in adult neurons in DISC1 knockdown mice resulted in over-extended migration of newborn neurons, aborization, and abnormal electrophysiological response. DISC1 does not appear to confer these changes in isolation; Duan et al. reported similar findings for Ndel1, a DISC1 signalling partner. Other reported signalling partners include LIS1, NDE1, PDE4B, 14-3-3e, Grb2, and FEZ1, each of which are also implicated in neural cell growth and/or migration (Porteous \& Millar, 2006; Chubb et al. 2008). In addition to DISC1 being involved in the development of post-mitotic neurons, Mao et al. (2009) report that DISC1 also regulates the proliferation of embryonic and adult neural progenitor cells through the GSK3 $\beta / \beta$-catenin pathway. Furthermore, GSK3 inhibitors were shown to normalize progenitor proliferation and the behavioural defects caused by DISC1 loss-of-function mutations.

These subtle changes in neuronal growth and migration, particularly in the hippocampus, have been examined in terms of their association with changes in cognitive function, particularly in hippocampusdependent memory function. In the original discovery of the DISC1 locus, one of the most interesting phenotypic aspects of carriers of $1: 11$ translocation was that all of the carriers, but none of the non-carriers showed deficits in the $\mathrm{P} 300$ response, which is thought to provide an index of memory and attention. Since this initial finding, association between risk variants at DISC1 and deficits in cognition have been reported in multiple studies, primarily in the area of memory function (Burdick et al. 2005; Cannon et al. 2005). At one level, the agreement between studies is surprising given the alternative SNPs and haplotypes tested. Association of the Ser allele of Ser704Cys with reduced hippocampal grey-matter volume may reflect a specific effect of DISC1's role in brain development, which is being expressed by deficits on memory tasks.

\section{Small structural changes (DNA CNV) in the genome and risk of psychosis}

Cytogenetic investigations have become increasingly sophisticated enabling the rapid characterization of identified chromosomal abnormalities but molecular techniques, initially confined to specific regions of the genome such as the telomeres, and more recently genome-wide are identifying a form of genetic variation between individuals consisting of small chromosomal abnormalities known as CNVs (Sebat et al. 2004). It is likely that this form of DNA variation is at least as common, if not more so, as sequence variation, accounting for a difference between random individuals of $0.12 \%$, compared to a difference of $0.08 \%$ at the sequence level (Sebat, 2007). Small genomic structural changes can be defined as deletions, insertions, duplications and inversions of kilobase to megabase size although the term CNV may be confined to those leading to changes in gene copy number (Korbel et al. 2008). CNVs are likely to be important in the evolution of higher organisms with duplicated genes becoming free to develop new functions. In addition, CNVs seem to relate to proteins involved in response to the environment, a finding that may be relevant to the psychoses.

Samples of patients with schizophrenia and other psychoses have been surveyed using $\mathrm{CNV}$ detection technologies (Wilson et al. 2006; Moon, 2006). Because techniques are still developing, the frequencies reported might be inaccurate. However, if the genomewide methods are followed with experimental validation then the figures given are likely to be conservative. Novel deletions and duplications appear to be more common in cases of schizophrenia (15\%) compared to controls (5\%) and especially so for very early onset cases (Walsh et al. 2008). Walsh et al. identified several gene pathways and processes that were over-represented by genes affected by duplications and deletions in the schizophrenia cases, including amongst others, glutamate receptor signalling, neuregulin signalling, synaptic long-term potentiation and nitric oxide signalling. Many of these gene families have already been implicated in psychoses. These findings suggest that schizophrenia can be caused by rare mutations that disrupt genes in pathways of neuronal development and regulation.

Two recent surveys [International Schizophrenia Consortium (ISC), 2008; Stefansson et al. 2008], using 
different technologies to the Walsh et al. (2008) paper have confirmed that rare chromosomal deletions and duplication increase risk for schizophrenia and have identified specific deletions on chromosomes $15 q 11.2$ $15 q 13.3$ and 1q21.1 in multiple cases similar in frequency to the $22 \mathrm{q}$ deletions seen in cases of schizophrenia with VCFS. Even though very rare, the OR are $21.6-\propto$ for the $22 q 11.2$ deletion, 3.9 for $15 q 11.2$, 8.94-17.9 for $15 q 13.2$, and $6.6-8.68$ for $1 q 21$. The $15 q$ region is consistent with a deleted region reported in cases of mental retardation with seizures and five of the nine patients with schizophrenia had mild cognitive impairment and one had a history of seizures. The $1 \mathrm{q}$ region was previously reported in some cases of autism and in a patient with learning disability and epilepsy. In the second survey, de-novo CNVs were identified in a family-based sample and tested for association in a further sample of cases. As well as the two loci in the ISC (2008) report, an additional locus at $15 \mathrm{q} 11.2$ was identified. These events are a rare cause of disorder; for example, the $15 q 11.2$ deletion occurred in $0.55 \%$ of cases compared to $0.19 \%$ of controls. This deletion, $\sim 470 \mathrm{~kb}$ in length is consistent with a region deleted in a small number of cases of Angleman and Prader-Willi syndromes and includes the gene CYFIP1, which interacts with the fragile $\mathrm{X}$ mental retardation protein as well as $R A C 1$, which is involved in regulating axonal guidance and dendritic outgrowth, functions similar to the DISC1 gene. Cases of fragile $X$ and obligate carriers show features of autism with attentional deficits and psychotic symptoms. The $15 \mathrm{q}$ deletion contains the CHRNA7 gene, previously implicated in schizophrenia. This gene is targeted to axons by neuregulin 1, described above.

The evidence that CNVs are causative of schizophrenia is both statistical and biological. There is an increased frequency of some CNVs individually, and CNVs collectively in cases compared to controls. They target gene pathways that could plausibly be involved in the disease (Walsh et al. 2008), and several CNVs have arisen de novo and affect known candidate genes. De-novo copy number mutations appear to be up to eight times more common in sporadic cases, but not familial cases, compared to controls ( $\mathrm{Xu}$ et al. 2008). These authors argue that the marked and specific enrichment of rare de-novo CNVs in sporadic cases is strong evidence that they are highly likely to contribute to the disorder. Other studies of CNVs have focused on a given region of the genome or indeed a single gene. Rujescu et al. (2009) report a study of neurexin genes showing a frequency for deletions and duplications disrupting neurexin 1 of $0.47 \%$ in cases compared to $0.15 \%$ in controls, an OR of $\sim 9$ (compared to an OR of $\sim 30$ for VCFS). Mutations in neurexin 1 were previously described in a sibling pair with schizophrenia and their unaffected mother (Kirov et al. 2008). They are also described in autism (Kim et al. 2008) and consistent with that literature, the common theme in these mutations is disruption of the gene itself rather than a sharing of size and breakpoints. Neurexin is found predominantly at the presynaptic membrane and functions as a neuroligin receptor. This creates a trans-synaptic complex involved in excitatory glutaminergic and inhibitory GABAergic synapses (Craig \& Kang, 2007). In turn, neuroligin binds a set of scaffold proteins in the membrane associated with the guanylate kinase family that includes PSD-93 that have been reported as affected by CNVs in schizophrenia (Walsh et al. 2008). A further study (Friedman et al. 2008) has identified CNVs in CNTNAP2 in some cases of schizophrenia. The CNTNAP2 encoded protein is a member of the neurexin super-family. A further $\mathrm{CNV}$ was reported in a single case in the $A P B A 2$ gene, the protein of which binds neurexins. These genes link with the neuregulin gene and its interacting partners ERBB4 and MAG12 through PSD-95, the protein of which recruits ERBB4 to the neurexin-neuroligin complex (see Südhof et al. 2008 for a review of neurexin function).

The emerging findings from analyses of CNVs are that they are more common in cases, particularly early onset cases, cluster in certain regions of the genome, account for small but significant numbers of cases, and involve neurodevelopmental, cell signalling, and synaptic function genes. They may be recurrent, such as with VCFS, chromosomes 1q21.1, 15q11.2, and 15q13.3; affect particular genes, such as neurexin 1, unique in cases but inherited, or occur de novo. The de-novo findings are more common in sporadic than in familial cases and provide a source of new mutation, contributing to the persistence of schizophrenia in all populations despite its association with reduced fecundity (Stefansson et al. 2008).

Apart from Alzheimer's disease; identifying neuregulin, dysbindin, DISC1 and neurexin 1; rare CNVs and new mutations affecting genes involved in neurodevelopment, cell signalling and synaptic function; overlapping genetic architecture with other developmental disorders including autism; and with new mutations offering an explanation for the familial sporadic divide and the persistence of schizophrenia in the population, what has the genomics done for the psychoses?

\section{Novel genes identified through GWAS?}

GWAS have the power to detect DNA variation of small risk effect and have the major advantages of being unbiased regarding genome location and requiring 
no prior knowledge of disease aetiology. They have been enormously successful in a very few years since they became technically and financially practical in multiple complex genetic disorders and traits. The National Human Genome Research Institute's catalogue of published GWAS included 254 publications identifying 788 SNPs associated with a significance value of $p<1.0 \times 10^{-8}$ (Hindorff et al. 2009). GWAS studies in schizophrenia and other psychiatric disorders are beginning to appear in this catalogue. The first studies reported used DNA pooling techniques for economic reasons. Kirov et al. (2008) studied 574 parent proband trios following up the most significant findings using individual genotyping. Their best result was within the gene CCDC60 and their third best within RBP1, a cellular retinol-binding protein that inhibits PI3K/Akt signalling, a previously suggested pathway in schizophrenia pathogenesis. Shifman et al. (2008) used the same technique in an initial population of Ashkenazi Jews and identified variants of the RELN gene as associated in women only with replication of the sex-specific association in further samples. Reelin, the protein product of the RELN gene is involved in neurodevelopment, in particular corticogenesis. Mutations in this gene cause lissencephaly, a neurodevelopmental syndrome with mental retardation. The first fully individually typed GWAS using reasonably sized samples (Sullivan et al. 2008) identified only a set of promising SNPs for further study with no result reaching genome-wide significance. O'Donovan et al. (2008) in a genome-wide study with extensive follow-up of 12 loci tested at $p<1.0 \times 10^{-5}$ in multiple samples. Three of these loci provided independent support in the follow-up samples including ZNF804A, which provided the greatest statistical evidence on meta-analysis, and especially so when the phenotype included bipolar disorder. The function of the protein is unknown, but its predicted zinc ion and DNA-binding domains suggest a role in gene expression regulation. Investigating the effect of this variant on cortical connectivity in healthy participants, Esslinger et al. (2009) found that risk-allele carriers showed reduced connectivity both within and between the two dorsolateral prefrontal cortex (DLPFC) areas, increased connectivity between the hippocampal formation and the DLPFC, and between the amygdala and the hippocampus, orbitofrontal cortex, and medial prefrontal cortex. Examining brain function at the level of cognition (J. T. Walters et al. unpublished observations) showed that the risk allele was also associated with altered neuropsychological performance in episodic and working memory, cognitive functions closely related to the areas of the brain highlighted in the Esslinger et al. (2009) study.
Additional large-scale GWAS are beginning to emerge or are completed and awaiting publication. The first of these relates to the sample on which the ISC (2008) published their findings on CNVs. In more than 3000 cases and a similar number of controls, the strongest association findings occurred within the myosin XVIIIB gene on chromosome 22, and intriguingly, given the history of linkage studies in schizophrenia, a large number of SNPs on chromosome $6 \mathrm{p}$ covering the major histocompatibility complex (MHC). The strongest SNP association which, with imputed data, reached genome-wide significance, is in the MHC $7 \mathrm{~kb}$ from NOTCH4, a gene previously associated with schizophrenia.

The ISC study also tested the polygenic theory of schizophrenia inheritance by using the ISC sample as a 'discovery' sample, and used SNPs showing nominal association at different levels of significance to test 'target' samples from independent GWAS samples to determine if the nominally associated alleles were enriched. The ISC sample generated SNPs that were highly enriched in three independent schizophrenia samples, estimating that up to a third of the variance in schizophrenia is accounted for by common polygenic variation lying somewhere within the ISC nominally associated SNPs. Interestingly, the same SNPs were also enriched in the WTCCC Bipolar Affective Disorder sample, but not in the other non-psychiatric disorders suggesting that a substantial proportion of risk variants are shared between the two disorders.

The results from further large-scale GWAS are awaited but the data from the ISC study suggests that even with sample sizes between 1000 and 3000 cases and similar or large numbers of controls, individually, these studies are underpowered to reliably detect genes of very minor effects. To address this problem, the Psychiatric GWAS Consortium Steering Committee has been established to conduct within and across disorder mega-analyses of as much GWAS data as can be obtained from publically available databases or through collaboration (Psychiatric GWAS Consortium Steering Committee, 2009). Final numbers for the schizophrenia part of the study are likely to be between 15000 and 20000 cases with a similar or larger number of controls. Additional sequencing studies are planned to attempt to identify rare variants, supported by the 1000 Genomes Internal Consortium (http:// www.1000genomes.org/page.php). Many additional risk variants should emerge from these studies providing novel leads into gene pathways underlying the biology of schizophrenia.

Will the genetic findings in psychoses translate into clinical practice? It is premature to make predictions as genomic research will continue for some time to be predominantly about discovery of underlying 
biological processes and these discoveries may have little immediate impact on clinical psychiatry. It is highly likely that they will have an ongoing impact on diagnostic classification. The recent large family study of schizophrenia and bipolar disorder in the Swedish population (Lichtenstein et al. 2009) provides convincing evidence that these two disorders share a common genetic aetiology. Taken together with emerging GWAS data showing risk variants associated with both disorders (O'Donovan et al. 2008) and a more general sharing of risk variants (International Schizophrenia Consortium, 2009), these findings have all but destroyed the dichotomous model of the psychoses (Craddock et al. 2006). However, their impact on the emerging DSM-V and ICD-11 classification systems is as yet unclear. A more complete understanding of the molecular mechanisms underlying the psychoses may indicate disease subtypes based on shared molecular mechanisms with implications for diagnosis, treatment and prognosis. Further work needs to be done with the emerging rare but more highly penetrant CNVs to determine if they index a particular phenotypic or endophenotypic form of disorder. Perhaps knowledge of particular mutations, for example, those implicating the neurexin 1 gene might, despite having a variable clinical presentation, plausibly respond to a therapy targeted at the downstream effects of the mutations. Indeed, novel therapies are highly likely to emerge only from a better understanding of biological mechanisms. However, even for diseases caused by highly penetrant mutations there are many challenges that remain to be overcome in translating genetic findings and tests into clinical practice (Rogowski et al. 2009).

Finally, apart from Alzheimer's disease; identifying neuregulin, dysbindin, DISC1, neurexin 1 and ZNF804A; rare CNVs and new mutations affecting genes involved in neurodevelopment, cell signalling and synaptic function; overlapping genetic architecture with other developmental disorders including autism; and with new mutations offering an explanation for the familial sporadic divide and the persistence of schizophrenia in the population; the functional effects of risk variants at the level of cognition and connectivity; re-identification of the MHC as a risk locus and the demonstration that at least a third of the variation in liability is due to multiple common risk variants of small effect; and a shared genetic liability between schizophrenia and bipolar affective disorder, is it any longer necessary to ask what the genomics has and is doing for the psychoses?

\section{Acknowledgements}

We thank Science Foundation Ireland, The Health Research Board, and the Wellcome Trust for financial support.

\section{Declaration of Interest}

None.

\section{References}

Aggarwal VS, Morrow BE (2008). Genetic modifiers of the physical malformations in velo-cardio-facial syndrome/ DiGeorge syndrome. Developmental Disability Research Reviews 14, 19-25.

Arinami T (2006). Analyses of the associations between the genes of 22q11 deletion syndrome and schizophrenia. Journal of Human Genetics 51, 1037-1045.

Austin CP, Ky B, Ma L, Morris JA, Shughrue PJ (2004). Expression of Disrupted-In-Schizophrenia-1, a schizophrenia-associated gene, is prominent in the mouse hippocampus throughout brain development. Neuroscience 124, 3-10.

Blackwood DH, Fordyce A, Walker MT, St Clair DM, Porteous DJ, Muir WJ (2001). Schizophrenia and affective disorders - cosegregation with a translocation at chromosome 1q42 that directly disrupts brain-expressed genes: clinical and P300 findings in a family. American Journal of Human Genetics 69, 428-433.

Bray NJ, Preece A, Williams NM, Moskvina V, Buckland PR, Owen MJ, O'Donovan MC (2005). Haplotypes at the dystrobrevin binding protein 1 (DTNBP1) gene locus mediate risk for schizophrenia through reduced DTNBP1 expression. Human Molecular Genetics 14, 1947-1954.

Burdick KE, Goldberg TE, Funke B, Bates JA, Lencz T, Kucherlapati R, Malhotra AK (2007). DTNBP1 genotype influences cognitive decline in schizophrenia. Schizophrenia Research 89, 169-172.

Burdick KE, Hodgkinson CA, Szeszko PR, Lencz T, Ekholm JM, Kane JM, Goldman D, Malhotra AK (2005). DISC1 and neurocognitive function in schizophrenia. Neuroreport 16, 1399-1402.

Burdick KE, Lencz T, Funke B, Finn CT, Szeszko PR, Kane JM, Kucherlapati R, Malhotra AK (2006). Genetic variation in DTNBP1 influences general cognitive ability. Human Molecular Genetics 15, 1563-1568.

Camargo LM, Collura V, Rain JC, Mizuguchi K, Hermjakob H, Kerrien S, Bonnert TP, Whiting PJ, Brandon NJ (2007). Disrupted in Schizophrenia 1 interactome: evidence for the close connectivity of risk genes and a potential synaptic basis for schizophrenia. Molecular Psychiatry 12, 74-86.

Cannon TD, Hennah W, van Erp TG, Thompson PM, Lonnqvist J, Huttunen M, Gasperoni T, TuulioHenriksson A, Pirkola T, Toga AW, Kaprio J, Mazziotta J, Peltonen L (2005). Association of DISC1/TRAX haplotypes with schizophrenia, reduced prefrontal gray matter, and impaired short- and long-term memory. Archives of General Psychiatry 62, 1205-1213.

Cedazo-Mínguez A (2007). Apolipoprotein E and Alzheimer's disease: molecular mechanisms and therapeutic opportunities. Journal Cellular and Molecular Medicine 11, 1227-1238. 
Chubb JE, Bradshaw NJ, Soares DC, Porteous DJ, Millar JK (2008). The DISC locus in psychiatric illness. Molecular Psychiatry 13, 36-64.

Corvin A, Donohoe G, Nangle JM, Schwaiger S, Morris D, Gill M (2008). A dysbindin risk haplotype associated with less severe manic-type symptoms in psychosis. Neuroscience Letters 431, 146-149.

Corvin AP, Morris DW, McGhee K, Schwaiger S, Scully P, Quinn J, Meagher D, Clair DS, Waddington JL, Gill M (2004). Confirmation and refinement of an 'at-risk' haplotype for schizophrenia suggests the EST cluster, Hs.97362, as a potential susceptibility gene at the Neuregulin-1 locus. Molecular Psychiatry 9, 208-213.

Craddock N, O'Donovan MC, Owen MJ (2006). Genes for schizophrenia and bipolar disorder? Implications for psychiatric nosology. Schizophrenia Bulletin 32, 9-16.

Craig AM, Kang Y (2007). Neurexin-neuroligin signaling in synapse development. Current Opinions in Neurobiology $17,43-52$.

Crow TJ (2008). The emperors of the schizophrenia polygene have no clothes. Psychological Medicine 38, 1681-1685.

Demirhan O, Taştemir D (2003). Chromosome aberrations in a schizophrenia population. Schizophrenia Research 65, 1-7.

Donohoe G, Morris DW, Clarke S, McGhee KA, Schwaiger S, Nangle JM, Garavan H, Robertson IH, Gill M, Corvin A (2007). Variance in neurocognitive performance is associated with dysbindin- 1 in schizophrenia: a preliminary study. Neuropsychologia $\mathbf{4 5}$, 454-458

Donohoe G, Morris DW, De Sanctis P, Magno E, Montesi JL, Garavan HP, Robertson IH, Javitt DC, Gill M, Corvin AP, Foxe JJ (2008). Early visual processing deficits in dysbindin-associated schizophrenia. Biological Psychiatry 63, 484-489.

Duan X, Chang JH, Ge S, Faulkner RL, Kim JY, Kitabatake Y, Liu XB, Yang CH, Jordan JD, Ma DK, Liu CY, Ganesan S, Cheng HJ, Ming GL, Lu B, Song H (2007). Disrupted-In-Schizophrenia 1 regulates integration of newly generated neurons in the adult brain. Cell 130, 1146-1158

Dubois PC, van Heel DA (2008). New susceptibility genes for ulcerative colitis. Nature Genetics 40, 686-688.

Egeland JA, Gerhard DS, Pauls DL, Sussex JN, Kidd KK, Allen CR, Hostetter AM, Housman DE (1987). Bipolar affective disorders linked to DNA markers on chromosome 11. Nature 325, 783-787.

Esslinger C, Walter H, Kirsch P, Erk S, Schnell K, Arnold C, Haddad L, Mier D, Optiz von Boberfeld C, Raab K, Witt SH, Rietschel M, Cichon S, Meyer-Lindenberg A (2009). Neural mechanisms of a genome-wide supported psychosis variant. Science 324, 605.

Fallgatter AJ, Herrmann MJ, Hohoff C, Ehlis AC, Jarczok TA, Freitag CM, Deckert J (2006). DTNBP1 (dysbindin) gene variants modulate prefrontal brain function in healthy individuals. Neuropsychopharmacology 31, 2002-2010.

Fanous AH, van den Oord EJ, Riley BP, Aggen SH, Neale MC, O'Neill FA, Walsh D, Kendler KS (2005). Relationship between a high-risk haplotype in the DTNBP1 (dysbindin) gene and clinical features of schizophrenia. American Journal of Psychiatry 162, 1824-1832.

Ferreira MA, O'Donovan MC, Meng YA, Jones IR, Ruderfer DM, Jones L, Fan J, Kirov G, Perlis RH, Green EK, Smoller JW, Grozeva D, Stone J, Nikolov I, Chambert K, Hamshere ML, Nimgaonkar VL, Moskvina V, Thase ME, Caesar S, Sachs GS, Franklin J, Gordon-Smith K, Ardlie KG, Gabriel SB, Fraser C, Blumenstiel B, Defelice M, Breen G, Gill M, Morris DW, Elkin A, Muir WJ, McGhee KA, Williamson R, MacIntyre DJ, MacLean AW, St CD, Robinson M, Van Beck $M$, Pereira AC, Kandaswamy R, McQuillin A, Collier DA, Bass NJ, Young AH, Lawrence J, Ferrier IN, Anjorin A, Farmer A, Curtis D, Scolnick EM, McGuffin P, Daly MJ, Corvin AP, Holmans PA, Blackwood DH, Gurling HM, Owen MJ, Purcell SM, Sklar P, Craddock N, Wellcome Trust Case Control Consortium (2008). Collaborative genome-wide association analysis supports a role for ANK3 and CACNA1C in bipolar disorder. Nature Genetics 40, 1056-1058.

Friedman JI, Vrijenhoek T, Markx S, Janssen IM, van der Vliet WA, Faas BH, Knoers NV, Cahn W, Kahn RS, Edelmann L, Davis KL, Silverman JM, Brunner HG, van Kessel AG, Wijmenga C, Ophoff RA, Veltman JA (2008). CNTNAP2 gene dosage variation is associated with schizophrenia and epilepsy. Molecular Psychiatry 13, 261-266.

Gothelf D, Schaer M, Eliez S (2008). Genes, brain development and psychiatric phenotypes in velo-cardiofacial syndrome. Developmental Disabilities Research Reviews 14, 59-68.

Hahn CG, Wang HY, Cho DS, Talbot K, Gur RE, Berrettini WH, Bakshi K, Kamins J, Borgmann-Winter KE, Siegel SJ, Gallop RJ, Arnold SE (2006). Altered neuregulin 1-erbB4 signaling contributes to NMDA receptor hypofunction in schizophrenia. Nature Medicine 12, 824-828.

Harrison PJ, Law AJ (2006). Neuregulin 1 and schizophrenia: genetics, gene expression, and neurobiology. Biological Psychiatry 60, 132-140.

Hennah W, Varilo T, Kestilä M, Paunio T, Arajärvi R, Haukka J, Parker A, Martin R, Levitzky S, Partonen T, Meyer J, Lönnqvist J, Peltonen L, Ekelund J (2003). Haplotype transmission analysis provides evidence of association for DISC1 to schizophrenia and suggests sex-dependent effects. Human Molecular Genetics 12, 3151-3159.

Hindorff LA, Junkins HA, Mehta JP, Manolio TA (2009). A catalog of published genome-wide association studies (www.genome.gov/26525384). Accessed 23 July 2009.

Hindorff LA, Sethupathy P, Junkins HA, Ramos EM, Mehta JP, Collins FS, Manolio TA (2009). Potential etiologic and functional implications of genome-wide association loci for human diseases and traits. Proceedings of the National Academy of Sciences USA 106, 9362-9367.

Iizuka Y, Sei Y, Weinberger DR, Straub RE (2007). Evidence that the BLOC-1 protein dysbindin modulates dopamine D2 receptor internalization and signaling but not D1 internalization. Journal of Neurosciences 27, 12390-12395. 
International Schizophrenia Consortium (2008). Rare chromosomal deletions and duplications increase risk of schizophrenia. Nature 455, 237-241.

International Schizophrenia Consortium (2009). Common polygenic variation contributes to risk of schizophrenia that overlaps with bipolar disorder. Nature 460, 748-752.

Jacobs PA, Brunton M, Frackiewicz A, Newton M, Cook PJL, Robson EB (1970). Studies on a family with three cytogenetic markers. Annals of Human Genetics 33, 325-336.

Karayiorgou M, Gogos JA (2004). The molecular genetics of the 22q11-associated schizophrenia. Brain Research. Molecular Brain Research 132, 95-104.

Kelsoe JR, Ginns EI, Egeland JA, Gerhard DS, Goldstein AM, Bale SJ, Pauls DL, Long RT, Kidd KK, Conte G, Housman DE, Paul, DM (1989). Re-evaluation of the linkage relationship between chromosome 11p loci and the gene for bipolar affective disorder in the Old Order Amish. Nature 342, 238-243.

Kilpinen H, Ylisaukko-Oja T, Hennah W, Palo OM, Varilo $T$, Vanhala R, Nieminen-von Wendt $T$, von Wendt L, Paunio T, Peltonen L (2008). Association of DISC1 with autism and Asperger syndrome. Molecular Psychiatry 13, 187-196.

Kim HG, Kishikawa S, Higgins AW, Seong IS, Donovan DJ, Shen Y, Lally E, Weiss LA, Najm J, Kutsche K, Descartes M, Holt L, Braddock S, Troxell R, Kaplan L, Volkmar F, Klin A, Tsatsanis K, Harris DJ, Noens I, Pauls DL, Daly MJ, MacDonald ME, Morton CC, Quade BJ, Gusella JF (2008). Disruption of neurexin 1 associated with autism spectrum disorder. American Journal of Human Genetics 82, 199-207.

Kirov G, Gumus D, Chen W, Norton N, Georgieva L, Sari M, O'Donovan MC, Erdogan F, Owen MJ, Ropers HH, Ullmann R (2008). Comparative genome hybridization suggests a role for NRXN1 and APBA2 in schizophrenia. Human Molecular Genetics 17, 458-465.

Korbel JO, Kim PM, Chen X, Urban AE, Weissman S, Snyder M, Gerstein MB (2008). The current excitement about copy-number variation: how it relates to gene duplications and protein families. Current Opinions in Structural Biology 18, 366-374.

Liao J, Kochilas L, Nowotschin S, Arnold JS, Aggarwal VS, Epstein JA, Brown MC, Adams J, Morrow BE (2004). Full spectrum of malformations in velo-cardio-facial syndrome/DiGeorge syndrome mouse models by altering Tbx1 dosage. Human Molecular Genetics 13, 1577-85.

Lichtenstein P, Yip BH, Björk C, Pawitan Y, Cannon TD, Sullivan PF, Hultman CM (2009). Common genetic determinants of schizophrenia and bipolar disorder in Swedish families: a population-based study. Lancet 373, 234-239.

López-Bendito G, Cautinat A, Sánchez JA, Bielle F, Flames N, Garratt AN, Talmage DA, Role LW, Charnay P, Marín O, Garel S (2006). Tangential neuronal migration controls axon guidance: a role for neuregulin- 1 in thalamocortical axon navigation. Cell 125, 127-142.

McIntosh AM, Moorhead TW, Job D, Lymer GK, Muñoz Maniega S, McKirdy J, Sussmann JE, Baig BJ,
Bastin ME, Porteous D, Evans KL, Johnstone EC, Lawrie SM, Hall J (2008). The effects of a neuregulin 1 variant on white matter density and integrity. Molecular Psychiatry 13, 1054-1059.

MacIntyre DJ, Blackwood DH, Porteous DJ, Pickard BS Muir WJ (2003). Chromosomal abnormalities and mental illness. Molecular Psychiatry 8, 275-287.

Mao Y, Ge X, Frank CL, Madison JM, Koehler AN, Doud MK, Tassa C, Berry EM, Soda T, Singh KK, Biechele T, Petryshen TL, Moon RT, Haggarty SJ, Tsai LH (2009). Disrupted in schizophrenia 1 regulates neuronal progenitor proliferation via modulation of GSK3beta/betacatenin signaling. Cell 136, 1017-1031.

Merikangas KR, Risch N (2003). Will the genomics revolution revolutionize psychiatry? American Journal of Psychiatry 160, 625-635.

Moon HJ, Yim SV, Lee WK, Jeon YW, Kim YH, Ko YJ, Lee KS, Lee KH, Han SI, Rha HK (2006). Identification of DNA copy-number aberrations by array-comparative genomic hybridization in patients with schizophrenia. Biochemical and Biophysical Research Communications 344, 531-539.

O'Donovan MC, Craddock N, Norton N, Williams H, Peirce T, Moskvina V, Nikolov I, Hamshere M, Carroll L, Georgieva L, Dwyer S, Holmans P, Marchini JL, Spencer CC, Howie B, Leung HT, Hartmann AM, Möller HJ, Morris DW, Shi Y, Feng G, Hoffmann P, Propping P, Vasilescu C, Maier W, Rietschel M, Zammit S, Schumacher J, Quinn EM, Schulze TG, Williams NM, Giegling I, Iwata N, Ikeda M, Darvasi A, Shifman S, He L, Duan J, Sanders AR, Levinson DF, Gejman PV, Cichon S, Nöthen MM, Gill M, Corvin A, Rujescu D, Kirov G, Owen MJ, Buccola NG, Mowry BJ, Freedman R, Amin F, Black DW, Silverman JM, Byerley WF, Cloninger CR (2008). Molecular Genetics of Schizophrenia Collaboration. Identification of loci associated with schizophrenia by genome-wide association and follow-up. Nature Genetics 40, 1053-1055.

Owen MJ (1992). Will schizophrenia become a graveyard for molecular geneticists? Psychological Medicine 22, 289-293.

Paylor R, Glaser B, Mupo A, Ataliotis P, Spencer C, Sobotka A, Sparks C, Choi CH, Oghalai J, Curran S, Murphy KC, Monks S, Williams N, O'Donovan MC, Owen MJ, Scambler PJ, Lindsay E (2006). Tbx1 haploinsufficiency is linked to behavioral disorders in mice and humans: implications for 22q11 deletion syndrome. Proceedings of the National Academy of Sciences USA 103, 7729-7734.

Paylor R, Lindsay E (2006). Mouse models of 22q11 deletion syndrome. Biological Psychiatry 59, 1172-9.

Penrose LS (1971). Psychiatric genetics. Psychological Medicine 1, 265-266.

Pharoah PD, Antoniou AC, Easton DF, Ponder BAJ (2008). Polygenes, risk prediction and targeted prevention of breast cancer. New England Journal of Medicine 358, 2796-2803.

Porteous DJ, Millar JK (2006). Disrupted in schizophrenia 1: building brains and memories. Trends in Molecular Medicine 12, 255-261. 
Psychiatric GWAS Consortium Steering Committee (2009) A framework for interpreting genome-wide association studies of psychiatric disorders. Molecular Psychiatry 14, 10-17.

Rogowski WH, Grosse SD, Khoury MJ (2009). Challenges of translating genetic tests into clinical and public health practice. Nature Reviews Genetics 10, 489-495.

Rose S (1998). What is wrong with reductionist explanations of behaviour? Novartis Foundation Symposia 213, 176-186.

Rujescu D, Ingason A, Cichon S, Pietiläinen OP, Barnes MR, Toulopoulou T, Picchioni M, Vassos E, Ettinger $U$, Bramon E, Murray R, Ruggeri M, Tosato S, Bonetto C, Steinberg $S$, Sigurdsson E, Sigmundsson T, Petursson $H$, Gylfason A, Olason PI, Hardarsson G, Jonsdottir GA, Gustafsson O, Fossdal R, Giegling I, Möller HJ, Hartmann AM, Hoffmann P, Crombie C, Fraser G, Walker N, Lonnqvist J, Suvisaari J, Tuulio-Henriksson A, Djurovic S, Melle I, Andreassen OA, Hansen T, Werge T, Kiemeney LA, Franke B, Veltman J, Buizer-Voskamp JE; GROUP Investigators, Sabatti C, Ophoff RA, Rietschel M, Nöthen MM, Stefansson K, Peltonen L, St Clair D, Stefansson H, Collier DA (2009). Disruption of the neurexin 1 gene is associated with schizophrenia. Human Molecular Genetics 18, 988-996.

Sawamura N, Sawa A (2006). Disrupted-in-schizophrenia-1 (DISC1): a key susceptibility factor for major mental illnesses. Annals of the New York Academy of Sciences 1086, 126-133.

Schurov IL, Handford EJ, Brandon NJ, Whiting PJ (2004). Expression of disrupted in schizophrenia 1 (DISC1) protein in the adult and developing mouse brain indicates its role in neurodevelopment. Molecular Psychiatry 9, 1100-1110.

Schwartz JI, Dunbar S, Yuan J, Li S, Gipson A, Rosko K, Johnson-Levonas AO, Lasseter KC, Addy C, Stoch AS, Wagner JA (2008). Influence of taranabant, a cannabinoid-1 receptor inverse agonist, on pharmacokinetics and pharmacodynamics of warfarin. Advanced Therapeutics 25, 1175-1190.

Sebat J (2007). Major changes in our DNA lead to major changes in our thinking. Nature Genetics 39 (7 Suppl.), S3-5.

Sebat J, Lakshmi B, Troge J, Alexander J, Young J, Lundin P, Månér S, Massa H, Walker M, Chi M, Navin N, Lucito R, Healy J, Hicks J, Ye K, Reiner A, Gilliam TC, Trask B, Patterson N, Zetterberg A, Wigler M (2004). Large-scale copy number polymorphism in the human genome. Science 305, 525-528.

Sherrington R, Brynjolfsson J, Petursson H, Potter M, Dudleston K, Barraclough B, Wasmuth J, Dobbs M, Gurling H (1988). Localization of a susceptibility locus for schizophrenia on chromosome 5. Nature 336, 164-167.

Shifman S, Johannesson M, Bronstein M, Chen SX, Collier DA, Craddock NJ, Kendler KS, Li T, O'Donovan M, O'Neill FA, Owen MJ, Walsh D, Weinberger DR, Sun C, Flint J, Darvasi A (2008). Genome-wide association identifies a common variant in the reelin gene that increases the risk of schizophrenia only in women. PLoS Genetics 4, e28.
Stark KL, Xu B, Bagchi A, Lai WS, Liu H, Hsu R, Wan X, Pavlidis P, Mills AA, Karayiorgou M, Gogos JA (2008). Altered brain microRNA biogenesis contributes to phenotypic deficits in a 22q11-deletion mouse model. Nature Genetics 40, 751-760.

St Clair D, Blackwood D, Muir W, Carothers A, Walker M, Spowart G, Gosden C, Evans HJ (1990). Association within a family of a balanced autosomal translocation with major mental illness. Lancet 336, 13-16.

Stefanis NC, Trikalinos TA, Avramopoulos D, Smyrnis N, Evdokimidis I, Ntzani EE, Ioannidis JP, Stefanis CN (2007). Impact of schizophrenia candidate genes on schizotypy and cognitive endophenotypes at the population level. Biological Psychiatry 62, 784-792.

Stefansson H, Rujescu D, Cichon S, Pietiläinen OP, Ingason A, Steinberg $S$, Fossdal R, Sigurdsson E, Sigmundsson T, Buizer-Voskamp JE, Hansen T, Jakobsen KD, Muglia P, Francks C, Matthews PM, Gylfason A, Halldorsson BV, Gudbjartsson D, Thorgeirsson TE, Sigurdsson A, Jonasdottir A, Jonasdottir A, Bjornsson A, Mattiasdottir S, Blondal T, Haraldsson M, Magnusdottir BB, Giegling I, Möller HJ, Hartmann A, Shianna KV, Ge D, Need AC, Crombie C, Fraser G, Walker N, Lonnqvist J, Suvisaari J, TuulioHenriksson A, Paunio T, Toulopoulou T, Bramon E, Di Forti M, Murray R, Ruggeri M, Vassos E, Tosato $S$, Walshe M, Li T, Vasilescu C, Mühleisen TW, Wang AG, Ullum H, Djurovic S, Melle I, Olesen J, Kiemeney LA, Franke B; GROUP, Sabatti C, Freimer NB, Gulcher JR, Thorsteinsdottir U, Kong A, Andreassen OA, Ophoff RA, Georgi A, Rietschel M, Werge T, Petursson H, Goldstein DB, Nöthen MM, Peltonen L, Collier DA, St Clair D, Stefansson K (2008). Large recurrent microdeletions associated with schizophrenia. Nature 455, 232-236.

Stefansson H, Sigurdsson E, Steinthorsdottir V, Bjornsdottir S, Sigmundsson T, Ghosh S, Brynjolfsson J, Gunnarsdottir S, Ivarsson O, Chou TT, Hjaltason O, Birgisdottir B, Jonsson H, Gudnadottir VG, Gudmundsdottir E, Bjornsson A, Ingvarsson B, Ingason A, Sigfusson S, Hardardottir H, Harvey RP, Lai D, Zhou M, Brunner D, Mutel V, Gonzalo A, Lemke G, Sainz J, Johannesson G, Andresson T, Gudbjartsson D, Manolescu A, Frigge ML, Gurney ME, Kong A, Gulcher JR, Petursson H, Stefansson K (2002). Neuregulin 1 and susceptibility to schizophrenia. American Journal of Human Genetics 71, 877-892.

Südhof TC (2008). Neuroligins and neurexins link synaptic function to cognitive disease. Nature 455, 903-911.

Sullivan PF, Lin D, Tzeng JY, van den Oord E, Perkins D, Stroup TS, Wagner M, Lee S, Wright FA, Zou F, Lin W, Downing AM, Lieberman J, Close SL (2008). Genomewide association for schizophrenia in the CATIE Study: results of stage 1. Molecular Psychiatry 13, 570-584.

Talbot K, Eidem WL, Tinsley CL, Benson MA, Thompson EW, Smith RJ, Hahn CG, Siegel SJ, Trojanowski JQ, Gur RE, Blake DJ, Arnold SE (2004). Dysbindin-1 is reduced in intrinsic, glutamatergic terminals of the hippocampal formation in schizophrenia. Journal of Clinical Investigation 113, 1353-1363. 
Urban AE, Korbel JO, Selzer R, Richmond T, Hacker A, Popescu GV, Cubells JF, Green R, Emanuel BS, Gerstein MB, Weissman SM, Snyder M (2006). High-resolution mapping of DNA copy alterations in human chromosome 22 using high-density tiling oligonucleotide arrays. Procedures of the National Academy of Sciences USA 103, 4534-4539.

van den Oord EJ (2002). Association studies in psychiatric genetics: what are we doing? Molecular Psychiatry 7, 827-828.

Walsh T, McClellan JM, McCarthy SE, Addington AM, Pierce SB, Cooper GM, Nord AS, Kusenda M, Malhotra D, Bhandari A, Stray SM, Rippey CF, Roccanova P, Makarov V, Lakshmi B, Findling RL, Sikich L, Stromberg T, Merriman B, Gogtay N, Butler P, Eckstrand K, Noory L, Gochman P, Long R, Chen Z, Davis S, Baker C, Eichler EE, Meltzer PS, Nelson SF, Singleton AB, Lee MK, Rapoport JL, King MC, Sebat J (2008). Rare structural variants disrupt multiple genes in neurodevelopmental pathways in schizophrenia. Science 320, 539-543.

Wang K, Zhang H, Ma D, Bucan M, Glessner JT, Abrahams BS, Salyakina D, Imielinski M, Bradfield JP, Sleiman PM, Kim CE, Hou C, Frackelton E, Chiavacci R, Takahashi N, Sakurai T, Rappaport E, Lajonchere CM, Munson J, Estes A, Korvatska O, Piven J, Sonnenblick LI, Alvarez Retuerto AI, Herman EI, Dong H, Hutman T, Sigman M, Ozonoff S, Klin A, Owley T, Sweeney JA, Brune CW, Cantor RM, Bernier R, Gilbert JR, Cuccaro ML, McMahon WM, Miller J, State MW, Wassink TH, Coon H, Levy SE, Schnitz RT, Nurnberger JI, Haines JL, Sutcliffe JS, Cook EH, Minshew NJ, Buxbaum JD, Dawson G, Grant SF, Geschwind DH, Pericak-Vance MA, Schelienberg GD, Hakonarson H (2009). Common genetic variants on 5p14.1 associate with autism spectrum disorders Nature 459, 528-533.

Weickert CS, Straub RE, McClintock BW, Matsumoto M, Hashimoto R, Hyde TM, Herman MM, Weinberger DR, Kleinman JE (2004). Human dysbindin (DTNBP1) gene expression in normal brain and in schizophrenic prefrontal cortex and midbrain. Archives of General Psychiatry 61, 544-555.

Williams NM, O'Donovan MC, Owen MJ (2005). Is the dysbindin gene (DTNBP1) a susceptibility gene for schizophrenia? Schizophrenia Bulletin 31, 800-805.

Wilson GM, Flibotte S, Chopra V, Melnyk BL, Honer WG, Holt RA (2006). DNA copy-number analysis in bipolar disorder and schizophrenia reveals aberrations in genes involved in glutamate signaling. Human Molecular Genetics 15, 743-749.

Xu B, Roos JL, Levy S, van Rensburg EJ, Gogos JA, Karayiorgou M (2008). Strong association of de novo copy number mutations with sporadic schizophrenia. Nature Genetics 40, 880-885.

Zeggini E, Scott LJ, Saxena R, Voight BF, Marchini JL, Hu T, de Bakker PI, Abecasis GR, Almgren P, Andersen G, Ardlie K, Boström KB, Bergman RN, Bonnycastle LL, Borch-Johnsen K, Burtt NP, Chen H, Chines PS, Daly MJ, Deodhar P, Ding CJ, Doney AS, Duren WL, Elliott KS, Erdos MR, Frayling TM, Freathy RM, Gianniny L, Grallert H, Grarup N, Groves CJ, Guiducci C, Hansen T, Herder C, Hitman GA, Hughes TE, Isomaa B, Jackson AU, Jorgensen T, Kong A, Kubalanza K, Kuruvilla FG, Kuusisto J, Langenberg C, Lango H, Lauritzen T, Li Y, Lindgren CM, Lyssenko V, Marvelle AF, Meisinger C, Midthjell K, Mohlke KL, Morken MA, Morris AD, Narisu N, Nilsson P, Owen KR, Palmer CN, Payne F, Perry JR, Pettersen E, Platou C, Prokopenko I, Qi L, Qin L, Rayner NW, Rees M, Roix JJ, Sandbaek A, Shields B, Sjögren M, Steinthorsdottir V, Stringham HM, Swift AJ, Thorleifsson G, Thorsteinsdottir U, Timpson NJ, Tuomi T, Tuomilehto J, Walker M, Watanabe RM, Weedon MN, Willer CJ, Wellcome Trust Case Control Consortium, Illig T, Hveem K, Hu FB, Laakso M, Stefansson K, Pedersen O, Wareham NJ, Barroso I, Hattersley AT, Collins FS, Groop L, McCarthy MI, Boehnke M, Altshuler D (2008). Meta-analysis of genome-wide association data and large-scale replication identifies additional susceptibility loci for type 2 diabetes. Nature Genetics 40, 638-645. 